\title{
Researchers strike back in animal-rights row
}

David Adam, London

A group of charities is to move its bank account following its bank's refusal to guarantee that it would stand up to public protests against animal research.

The Association of Medical Research Charities (AMRC) said on 23 April that it would close its account with the HSBC bank after the HSBC refused to confirm that it would stand by customers if they were targeted by animal-rights activists.

The HSBC was criticized recently for bowing to animal-rights campaigners when it joined other banks and stockbrokers in refusing to handle shares in the drug-testing group Huntingdon Life Sciences (HLS) following threats from activists.

The AMRC's move is seen as part of a trend towards more aggressive tactics by British medical researchers in their publicrelations war against animal-rights activists.

For example, the BioIndustry Association, which represents the UK biotechnology industry, wrote to venture capitalists in March urging them not to cave in to antivivisection protesters. And in a joint letter to The Times newspaper last week, the heads of a dozen academic and commercial research organizations pointed to the "huge contribution that laboratory animal research has
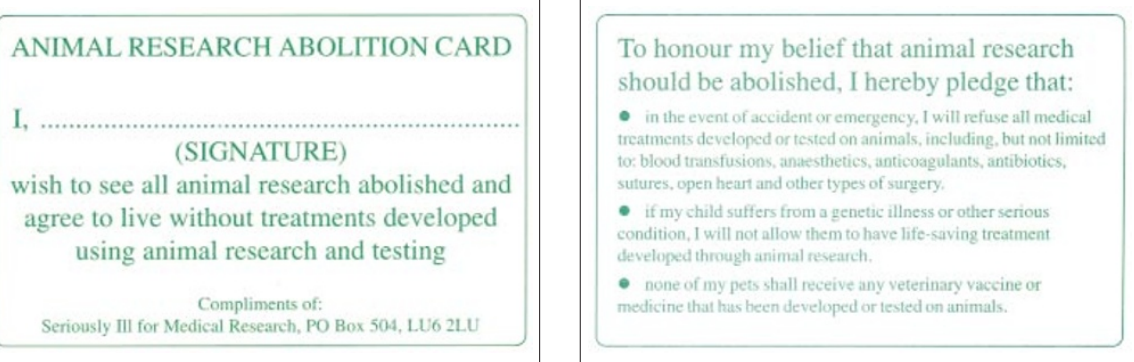

Making a point: animal-rights activists might try carrying this card, their opponents suggest.

made to medical science”. The patients' group Seriously Ill for Medical Research has sent spoof donor cards to animal-rights protesters asking them to refuse medical treatment.

An AMRC statement said: "Following recent targeting by animal rights activists of banks and investment funds, AMRC had sought assurances from HSBC that the bank would not give in to a similar campaign... AMRC executive council considered HSBC's responses unsatisfactory and has agreed to move its account."

The AMRC has a few hundred thousand pounds in its account, but its 112 members, which include the Wellcome Trust and the Cancer Research Campaign, have combined assets of almost $\mathfrak{E} 16$ billion (US $\$ 23$ billion).
Diana Garnham, the AMRC's chief executive, says she expects many of its charities to seek similar assurances from their banks. The Wellcome Trust says it is "keeping a careful eye on how events unfold".

A spokesman for HSBC says the bank was "disappointed" with the AMRC's decision. The association put the bank in an impossible position, he says, by demanding a " $100 \%$ legal guarantee" to stand by its members, whatever the circumstances.

The campaign against HLS included break-ins at its suppliers' factories and threats to its investors. In February, the company's managing director was attacked by masked assailants wielding baseball bats (see Nature 410, 8; 2001).

\section{Fungus fingered as dogwood disappears from forests}

\section{Mark Schrope}

Flowering dogwoods, Cornus florida, whose white blossoms were once a welcome and common sign of spring's arrival in the United States east of the Mississippi, are rapidly disappearing.

The loss is mainly the result of an exotic fungus called anthracnose (Discula destructiva), which causes lesions on leaves and trunks, and eventually kills the plant. The fungus was probably introduced into the United States decades ago on nursery trees from Asia, and was first spotted on the east coast in around 1976 before spreading rapidly throughout eastern states.

In a recent study in the Great Smoky Mountains National Park in Tennessee and North Carolina, for example, National Park Service forest ecologist Michael Jenkins and colleagues have found evidence of severe declines in the flowering dogwood population since the 1970s in a variety of forest habitats. Similarly dismal results have also been found in other states.

Peter White, a plant ecologist at the University of North Carolina in Chapel Hill and an author of the Great Smoky Mountains study, says that, although the fungus seems to be the cause of the population decline, other factors may have contributed to its spread. For instance, the end of older Native American practices such as intentional burning means that fire is now far less prevalent. This results in thicker forest canopy and increased moisture, which helps the fungus to thrive.

The dogwood population has also declined in Indiana's Ross Biological Reserve, but not as severely as in the Smoky Mountains. Kerry Rabenold, a bird ecologist at Purdue University in West Lafayette, Indiana, says the reserve has also experienced changes that would help the fungus to spread, such as less fire. But anthracnose has not been found there.

Changes in the make-up of the forest appear to be affecting the reserve's dogwood population. Less fire helps maple trees to thrive, forming a denser canopy that stops dogwoods getting the amount of sunlight they need. Rabenold says that other understorey trees not susceptible to the fungus have also been dying off.

Dogwoods are an important part of the forest ecosystem. They are a source of calcium for animals and plants, for example,

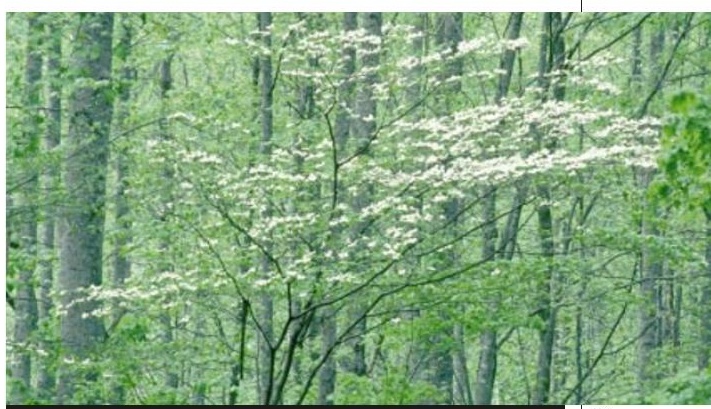

Blooming lovely: but the flowering dogwood is in decline on the Great Smoky Mountains.

drawing it from deep soil and concentrating it in their leaves.

The trees also produce berries, which Rabenold says are "probably the best food in North America for songbirds". He believes that declines in dogwood have adversely affected bird populations.

White says effects similar to those cited in the Indiana work are probably at play in other areas with dwindling dogwood populations, but that, in his study and many others, anthracnose is the clear culprit. "You might compare it to being run over by truck versus a chronic disease," he says. 